\title{
Microfinance Recipients' Maximum Willingness to Pay for Microloans in Lahore
}

\author{
Gul Andaman \\ (Senior Teaching Fellow, Department of Economics, Lahore School of Economics, Pakistan)
}

\begin{abstract}
Charging high interest rates is important for any microfinance institution's financial independence and sustainability. Optimal allocation of micro credits is when various amounts of loans are disbursed to those households that are willing and able to pay much needed high interest rate. This study attempts to measure the maximum amount microfinance recipients are willing to pay for purchasing a microloan. Using binary logit regression model for the most popular loan amounts, we observed that willingness to pay increased significantly if the recipient belonged to a female headed household. For higher loan levels, however, households with 'joint' household heads and additional factors such as higher income and lower expenditure became more important in raising the willingness to pay higher interest rate. Secondly, loan takers were willing to pay high if they invested in services/retail sector. Fixed effects model showed that for charging high interest rates, loans should be directed towards individual females, or those who have already purchased a loan and have strong savings pattern. Analysis also showed recipients were not interest-elastic.
\end{abstract}

Keywords: Interest rates, Microfinance Institutions, Microloans, Willingness to pay

\section{Introduction}

Microfinance is based on the idea that banks, specialized microfinance institutions (MFI) and NGOs can lend small sums, often no more than a few hundred American dollars, to poor entrepreneurs. Mohammad Yunus, the Nobel Peace Prize winner (2005), and the founder of Grameen Bank is the pioneer for microcredits. He said:

"I made a list of people who needed just a little bit of money. And when the list was complete, there were 42 names. The total amount of money they needed was \$27. I was shocked." (Muhammad Yunus, economist and founder of the Grameen Bank on how micro credit began)

Microcredits are imperative for those people who have been neglected by the mainstream commercial banks due to lack of income and status and thus have not been appropriated deserving loans. Such people want loans to prove their entrepreneurial abilities and get out of the poverty trap. The loan recipients open businesses like tailoring shops or small grocery stores, thereby bolstering local economies. Thus microfinance is also an essential tool for attaining a macro level objective of sustainable economic growth, especially in a developing economy.

There are approximately 20 networks listed in Pakistan Microfinance Network. Some of the projects working for micro credits in Pakistan are Development Action for Mobilization and Emancipation (DAMEN), Kashf Foundation, National Rural Support Program (NRSP), Khushali Bank, etc. Mahmood and Rouf (2009) [1] evaluated the growth and performance of microfinance in Pakistan and they came up with numerous problems in terms of poor targeting, financial dependence, risk of sustainability, etc. Also, according to Farhat Abbas Shah, CEO, Farz Foundation (2012):

"In Pakistan, the microfinance sector is about thirteen years old and only a playful financial teenager in Pakistan, while it is rapidly getting maturity in rest of the countries like Bangladesh, Malaysia, Indonesia and India. With reference to Pakistan, sector is facing still the stereo type style of management..."

Therefore, although microcredit has immense economic importance, the existing MFIs in Pakistan suffer from ineffective targeting of loans and poor management. In fact, much remains to be seen on how microfinance programs perform in future and how effectively untapped demand is locked in.

It is obvious that microfinance loans don't come free of cost. Recipients pay for them in the form of 'interest rates'. Setting interest rate is essential as it helps in attracting efficient customers who have enough confidence in their investment and can pay back the loan. The other function of interest rates is to cover the costs of institutions that come in the form of operating costs, transaction costs, etc. It is observed that interest rates charged on micro loans are very high and often termed as usury, or excessive interest rates. Fernando 
(2006) [2] explained in detail the rationale behind the high interest rates. To sustain its operations, MFI cannot rely permanently on concessional funds and thus ultimately charge higher interest rates in order to become selfsufficient. This can be a problem for a developing economy whereby the returns on the best use of microloan are moderate and for such recipients, interest servicing can be a difficult task. But if they consider recipients' concern, sustainability of an MFI becomes a difficult task. So it can be said that IF high interest rate is identified as an inherent characteristic of the MFI, then relatively higher-income recipients would be attracted. This may limit the AMOUNT of recipients but these loan holders are more certain of their small-scale productive investments and hence, can pay back the loans within the prescribed time limit and at the fixed interest rates. An institution can avoid the problem of asymmetric information and moral hazards if it sets high interest rates by automatically attracting those recipients who are more capable of paying back.

Having established the importance of setting high interest rates (obviously, at some expense) this study attempts to find out the maximum amount of interest rates recipients are willing to accept. If the recipient can pay higher interest rate, loan allocation would be more optimal. In Pakistan, interest rates on microloans vary from $15 \%$ to $30 \%$. However, are the recipients accepting an interest rate equal to $30 \%$ ? What is the amount that they are able to pay? The objective of the study is to examine the variables that increase the willingness to pay for a microloan so that targeting of loans can be done more effectively. It would also help in attracting right type of customers and in disbursing the right amount of loans thus making the loan allocation framework more efficient. It will also increase the customer base efficiently making an MFI more sustainable and financially independent.

Previous work done looked into the change in microfinance demand as interest rate increased irrespective of the loan size. Using binary logit estimation technique, we take into account a loan-specific analysis of the factors that significantly raise the interest rates any recipient is willing to pay. If factor significance differs across loans, it would indicate that specific amounts of microloans should be disbursed to specific households so that willingness to pay a higher interest rate, for a particular loan amount, can be fully extracted. This would simultaneously resolve the MFIs' supply side sustainability issue and the demand side loan targeting issue. It is for these reasons that a detailed analysis on the maximum willingness to pay for a microloan is important.

Section 2 looks at the existing literature explaining the presence of an MFI and its effect on poverty alleviation, repayment rates, interest rates and female empowerment. Section 3 explains the variables used, method of data collection and important summary statistics. Sections 4 and 5 analyze the data and describe the empirical results while Section 6 concludes the discussion with important recommendations and policy implications.

\section{Literature Review}

Since the inception of Grameen Bank, microfinance institutions have had a significant effect on the lives of the poor people. They have given not only hope to poor masses residing in the developing countries in terms of kick starting or expanding their businesses but have also influenced the social impact of microloans on female empowerment and education. Sengupta and Aubuchon (2008) [3] present a comprehensive overview on microfinance revolution. They evaluate the overall impact of microfinance on poverty reduction, sustainability of microfinance institutions, and repayment rates. The discussion in this section will draw heavily upon this paper and will include other debates on optimal level of interest rates for microloans as well.

\subsection{Financial Sustainability of Microfinance Institution and the Impact on Poverty Alleviation}

Sengupta and Aubuchon (2008) distinguish between two types of microfinance programs: subsidized and financially independent, the latter can be covering only the operational expenditures in which case, they can be operationally independent or can be making positive economic profits, gaining the status of financially sustainable institution. A microfinance lending institution can begin its operations through subsidies and money from private donors. Such institutions can lend at low interest rates and with perpetual government and international aid, they can continue lending at lower interest rates and be financially sustainable. In this scenario, the microfinance recipients would comprise of both, 'very poor' and 'marginally poor' categories. However, in order to gain financial independence, without any reliance on subsidies, it is of importance to an MFI to set high interest rates. The by-product of the high interest rates, as stated by Sengupta and Aubuchon, is the accumulation of 'marginally poor' customers.

The goal of Grameen Bank, which is considered to be a pioneer in the field of microfinance, is to alleviate poverty, even if it comes at the expense of profit. If a borrower is unable to pay back the loan in a certain month at a given interest rate, the bank doesn't write-off the loan immediately. It gives more time to the borrowers as the basic idea is based on 'trust' on the poor borrower that, given time, the customer would pay back in the future. Therefore, with unanimity on this goal, a huge network of microfinance institutions should reduce the poverty. However, with the passage of time, the objective of the institutions shifted from poverty 
alleviation to gaining the status of 'financial independence'. This transition in the objective propelled the institutions to charge high interest rates, which automatically attracted only the 'marginally poor' customers. Hence, the literature views a trade off between the financial sustainability of the microfinance institution and the goal of poverty reduction. Susan Davis, CEO of BRAC USA, a New York outpost of the successful Bangladeshi poverty-fighting nonprofit, warns that "As MFIs reach deeper into the for-profit capital pool, more and more of their investors will seek to maximize profits, potentially at the expense of the MFIs' social mission". Such ideas have already initiated a debate on the future operations and objectives of microfinance institutions.

Ayayi and Sene (2010) [4] report the factors that drive microfinance institution's financial sustainability. One of the foremost factors is the presence of high quality credit profile coupled with sufficiently high interest rates for a sound financial management and sustainability. This reinforces the trade off between financial sustainability and poverty reduction.

The primary effort of the microfinance institutions is to alleviate the poverty by providing poor people cheap source of credit. Khan (2008) [5] describes the failure of MFIs in Pakistan in materializing the stated primary objective. The donor community, that can include both private and public entities, changed their policies towards the microfinance institutions by refusing to provide any subsidies. For smooth operations, it became imperative for the institutions to become self-sustainable, which had an adverse effect on the interest rates, i.e. interest rates increased. Higher interest attracted relatively less poor customers. This result is consistent with other studies whereby, financial sustainability makes poverty reduction as a secondary goal.

An interesting twist to the trade-off described above is the study of Karlan and Zinman (2006) [6] in which the randomized study on a microlender in South Africa showed that micro loans with high interest rates were given to 'rejected applicants' and a usual group of applicants that were considered suitable for such high interest loans. The intervention improved the financial status and health conditions of the former group whereas these remained largely unchanged in the latter group of applicants. However, as suggested by the research in this field, more studies of these sorts should be implemented before making any concrete conclusions.

\subsection{Impact of Microfinance on Female Empowerment}

The idea behind this particular theme is that microfinance is generally distributed to a group of 4 to 6 women, with the objective of increasing female empowerment. Research on microfinance, as stated by Sengupta and Aubuchon (2008), shows that if the loan is disbursed to a woman in a household, she would consume it in a more productive manner. The welfare of the house, in terms of better education and nutrition of children and higher per capita household expenditure, would increase. It is also hypothesized that if the loan were given to a female, she would consequently gain a higher status in the family and be significant part of the decision making process of allocating expenditures on food or nonfood items. This would be eventually translated into enhanced female empowerment. However, Sengupta and Aubuchon (2008) also reported in the paper that practically speaking, microfinance did little to transform the status of the women within a family.

Duflo et al. (2009) [7], consistent with the other studies, show that in a first randomized evaluation of the impact of introducing micro-credits in Hyderabad, India, 15 to 18 months after the program took effect, no impact was observed on the measures of health and education, when loans were given to females only. Duflo et al. (2009) did not find any change in the women's decision-making when the authors compared the results of the areas where micro-credits were introduced to those where there was no intervention. Men in the household usually control most of the loans taken by women and, therefore, the impact of microfinance on female empowerment is not significant.

\subsection{Microfinance and Repayment Rates}

Morduch (2009) [8] reports that top micro lenders enjoyed high repayment rates of 98\%. Broadly speaking, there are two views that explain the elevated repayment rates. Firstly, the policies of lenders would focus on providing micro loans with flexible repayment periods. Microfinance is a source of an institutional credit given to the poor sectors of the society with the primary objective of maximizing the social welfare. As stated above, the idea is that the lenders would trust the poor borrowers to the extent that if they failed to pay back any installment agreed upon, the microfinance institution would give them more time and not write-off the loans. For example, Sengupta and Aubuchon (2008) explained the high repayment rates in the Grameen Bank using this approach. Therefore, historically speaking, the repayment rates of micro loans are huge.

Overtime, the second view justifying high repayment rates has gained more importance. The loans are disbursed based upon group-liability (also known as joint lending) contracts. If anyone of the members of the group defaults, the group defaults as a whole. As explained by Morduch (2009), this also meant that if any one of the group members failed to pay back, none of the group members would be eligible for future loans. Hence, future loans were promised only if previous loans were returned. There is inherently a strong incentive in this format of loan disbursement for the members to avoid any probability of default because otherwise, that would be a cause of social embarrassment for the poor customers. No one wants to be responsible for other's default. 
This also suggested that groups formed by the potential borrowers would be risk-averse and filled with much more productive ideas of consuming loans so that probability of default is low.

Gine and Karlan (2008) [9] study the impact on repayment rates with and without the group lending. They explain that there is rigidity in the standard model of group lending. If flexibility is introduced in the debt products, then the demand of loans could improve without any sacrifice in the repayment rates. Such a randomized experiment was carried out for three years in Philippines and it showed that higher amounts of individual-liability contracts did not increase the default among such clients. Field and Pande (2008) [10] experimented with changing the frequency of repayment period from weekly to monthly. Following up for a year, they found no change in the default. They also suggested that if customers are allowed to pay back on monthly basis, the transaction costs could be reduced substantially and savings could be channeled as loanable funds for 'very poor' customers. Rohini and Erica (2008) [11] also conducted such a study in India whereby it was proved that ".. lower frequency of payments could reduce transaction costs without increasing default rate". These experiments highlight the potential change in the repayment and loan disbursement models that could be more productive for the microfinance institutions.

\subsection{Demand of microfinance and Interest Rates}

Microfinance institutions charge a certain amount of interest rates on the loans given to the customers. Theoretically, the demand for loan size would fall as the interest rate increases. However, that is not the only factor that defines the relationship between microcredits and interest rates. Research on microfinance reveals that interest rates are generally high, ranging from $30 \%$ to $60 \%$, which could be attributed to both demand side and the supply side economics of microfinance.

Institutions that are subsidized could distribute micro loans at a lower price as they don't need to be generating profits from the lending operations. It is crucial for the institutions to achieve self-sustainability, which propels them to set high interest rates so that they can at least cover their operational expenses if the subsidies are removed. Sengupta and Auchubon (2008) explain that Grameen Bank was able to reduce the interest rates in early 1990s because it was operating under subsidies. However, subsidies and finances from private donors are usually given to a new institution so that investors can kick-start their business. Once the MFI is operational, has a huge outreach, subsidies decrease, and eventually are completely removed. At this point in time, interest rates increase as well.

Supply side faces high transaction costs of distributing small loans. Morduch et al. (2009) explain that microfinance institutions charge higher interest rates than conventional banks for the same loan size because of differences in cost structures. The authors show that if an institution is facing higher cost per unit then it will charge the most from the customers. The numbers of borrowers served by Bangladesh MFI are in millions but those are exceptions. Typically, the numbers of customers receiving micro loans are comparatively lower due to which economies of scale are hard to find. Morduch et al. (2009) suggests that given the cost data, nongovernmental microfinance institutions can charge the customers less fee if they are given more subsidies. Shankar (2007) [12] shows the composition of transaction costs in India. The most significant contributor is the compensation of the field worker, responsible for doing group loan transactions. In addition, the collection activity is expensive. Transactions costs are high because the screening process of customers is lengthy as there are no collaterals associated with a loan provision or any credit history of the borrower. In addition to this, the repayment periods starts on weekly basis as soon as the loan is disbursed and this adds to the transaction costs per unit.

Conventional view on demand for micro loans is that borrowers are interest-inelastic. Hence, in order to become financially sustainable, the lenders can get rid of the subsidies and charge high interest rates as numbers of customers would not fall because of inelastic demand for micro loans. This view is tested by Morduch (2005) [13] in an experiment conducted in Dhaka, Bangladesh. Results show that borrowers' demand for loan with respect to interest rate changes ranges from -0.73 to -1.04 . Less wealthy customers are more sensitive to changes in interest rates and resultantly, as interest rates are increased, the relatively wealthier customers accumulate as accountholders. Karlan and Zinman (2006) also measured the interest rate elasticity of demand for micro credits in South Africa. Demand curve is downward sloping and flat, which indicates that people are highly sensitive to changes in interest rates. This is the case especially for low-income borrowers. They also explain that borrowers are more sensitive to changes in repayment periods than to changes in interest rates. Hence, demand for a loan size depends on the interest rates charged on the loans and the repayment period.

Morshed et al. (2006) [14] attempt to answer the conflicting views about interest rate elasticity of demand for micro credits. It was previously thought that consumers face inelastic demand for micro loans and raising interest rates would increase the revenues of micro finance institutions. However, the econometric estimate is significantly negative showing that consumers are highly interest-sensitive. Morshed et al. (2006) explain this difference in women's maximum willingness to pay with respect to labor market imperfections. If 
the labor market is perfect, as in neoclassical case, there are no transaction costs. The labor market for poor female customers is almost absent or imperfect due to which the transactions costs of disbursing micro credits are high. These women have no collaterals (such as landholdings) or non-labor alternative source of income and thus, in order to prove their creditworthiness, they are willing to pay higher interest rates on nominal loan sizes. This also explained the puzzle of coexistence of high repayment rates along with high interest rates.

\section{Description of Data and Summary Statistics}

The objective of the paper is to measure the maximum interest rates people are willing to pay for respective loan levels ranging from Rs. 5000 to Rs. 100,000. Six levels of interest rates at respective loan levels were given to the recipient: $5 \%, 10 \%, 15 \%, 20 \%, 25 \%$ and $30 \%$. The survey was carried out in different regions of Lahore, Pakistan, where actual and potential customers resided. The information about actual recipients of microfinance was particularly taken from the two well-known microfinance institutions in Lahore, Pakistan, Kashf Foundation and Akhuwat. After carefully observing the characteristics of the actual households, such as monthly incomes, size of households and other features, potential recipients of micro loans were identified. Table 1 shows the names of the areas and the number of households interviewed.

Table 1: Potential and Actual Microfinance Recipients' Residential Areas

\begin{tabular}{|l|l|}
\hline Potential Residential Areas & Amount of households surveyed \\
\hline Ghari Shaow & 21 \\
\hline Dharampura & 21 \\
\hline Model Town & 13 \\
\hline Khotay Pind & 16 \\
\hline Farooqabad & 25 \\
\hline Near University of Engineering (UET) & 07 \\
\hline Actual Residential Areas & Amount of households surveyed \\
\hline Green Town & 16 \\
\hline Bedian & 11 \\
\hline Kot Lakh Path & 17 \\
\hline Bhatta Chowk & 13 \\
\hline
\end{tabular}

In order to capture true maximum willingness to pay, a bidding game was implemented with every potential customer in the sample of 160 households of Lahore. Each customer was first asked the highest amount of interest rate that he/she shall be willing to pay for respective loan levels. If that was rejected, secondhighest interest rate was presented and so forth. Also it was analyzed that if loan repayment period was altered from one year to two years, how would the demand for loans and choice of interest rates change.

As the primary objective of disbursing micro credits is reducing the extent of poverty, the data set including 160 households were filtered and only loans invested in businesses and other productive purposes were carried forward for econometric analysis. These amounted to 131 . We hypothesized that the maximum willingness to accept an interest rate for various loan levels would be a function of household characteristics, characteristics of business for which the loan is being taken, business sector in which the loan is being used and the preferences for taking a micro loan, such as individually or in group, etc.

The following table explains the operational definitions of variables used in determining the amount of interest rates the microfinance recipients were willing to pay at every loan level. Other variables included general information regarding the 'age', 'gender' and 'locality' of the person being interviewed.

Table 2: Description of the Variables Used

\begin{tabular}{|l|l|}
\hline Variable & Explanation \\
\hline WTP & Willingness to Pay, i.e. the interest rate chosen for a particular loan level \\
\hline $\begin{array}{l}\text { Household Head: } \\
\text { Coded as: }\end{array}$ & $\begin{array}{l}\text { The one who takes decisions in the house. } \\
\text { Female: 1, Otherwise: } 0\end{array}$ \\
\hline Size of Household & Number of people that resided in a house \\
\hline Income & Income of household per month in PKR \\
\hline Expenditure & $\begin{array}{l}\text { Proportion of the income spent on food, clothing, utility bills, transport, } \\
\text { education, rents and any other activity. The total amount of expenditure for } \\
\text { the household per month in PKR }\end{array}$ \\
\hline Savings & Income less the expenditures per month in PKR \\
\hline
\end{tabular}




\begin{tabular}{|c|c|}
\hline $\begin{array}{l}\text { Usage of Loan: } \\
\text { Coded as Dummy: }\end{array}$ & $\begin{array}{l}\text { Need loan for initiating business, expanding the established business, for } \\
\text { education, marriage or other purposes } \\
\text { Which sector of economy will it belong to: Services, Manufacturing, Retail, } \\
\text { or Household - } 4 \text { sectors, } 3 \text { dummy variables }\end{array}$ \\
\hline $\begin{array}{l}\text { Size of Business (if } \\
\text { applicable) }\end{array}$ & Amount of loan required \\
\hline $\begin{array}{l}\text { Dummy for Loan- } \\
\text { taking }\end{array}$ & $\begin{array}{l}1 \text { - if wanted to be taken individually and } 0 \text { - if loan was preferred to be taken } \\
\text { in groups }\end{array}$ \\
\hline $\begin{array}{l}\text { Dummy for other } \\
\text { sources of non- } \\
\text { labor income }\end{array}$ & $1-$ if Yes \\
\hline $\begin{array}{l}\text { Dummy for } \\
\text { Preference of } \\
\text { Microsaving acc. }\end{array}$ & $\begin{array}{l}\text { People who wanted to open up their micro savings accounts and were willing } \\
\text { to pay Rs150 to Rs1000 } \\
1 \text { - if Yes }\end{array}$ \\
\hline $\begin{array}{l}\text { Perceptions of } \\
\text { Mircoloan } \\
\text { recipients }\end{array}$ & $\begin{array}{l}\text { Variables that measured what was important when purchasing a micro loan. If } \\
\text { a variable was most important, it would be rated } 1 \text { and } 8 \text { meant that the } \\
\text { subject variable is least important. The variables were access to loan, } \\
\text { complexity of loan application procedure, attitude of employees, customer } \\
\text { services, travel costs, products available such as micro credits, micro } \\
\text { insurance, micro savings, etc., permission from the household, certainty of } \\
\text { income, that is the certainty that income would be aviable to pay back the } \\
\text { loan amount in future. }\end{array}$ \\
\hline $\begin{array}{l}\text { Marital Status } \\
\text { (MS1) }\end{array}$ & 1 - if Married, 0 - Other \\
\hline EMP Dummy & Female Employed: 1, Other: 0 \\
\hline $\begin{array}{l}\text { Proportion } \\
\text { Employed }\end{array}$ & Number of employed people in house/Total household Size \\
\hline $\begin{array}{l}\text { Proportion } \\
\text { Educated }\end{array}$ & $\begin{array}{l}\text { Measured the number of children educated in a household. If there were } 2 \\
\text { children, who went to school but actually, the children who could have gone } \\
\text { to school were } 6 \text {, then } 2 / 6 \text { would be the value of EDU1 }\end{array}$ \\
\hline
\end{tabular}

Out of 160 observations, there were $65 \%$ were females and of those, $17.6 \%$ were employed of which $14.55 \%$ were married and $3.09 \%$ were unmarried. However, out of total sample, $27 \%$ of the females were employed. Other than the monthly incomes, only $23 \%$ or 36 people had other sources such as savings, committees, etc. More than $50 \%$ of the observations wanted to open up a micro savings account in Lahore. It was also observed that on average, out of total household size, the number of people involved in education was approximately $46 \%$. As expected, the highest education levels concentrated around primary and secondary levels. Besides, the number of people employed out of total household size is only $32 \%$. We see that higher education is not leading to higher employment and thus, it would be interesting to see the impact of these two variables on one's willingness to pay.

The following tables present a summary of people's preferences on the sector/service the loan was to be invested.

Table 3: Use of Loan Taken

Source: Author's calculations.

\begin{tabular}{|l|c|l|c|}
\hline \multicolumn{1}{|c|}{ Use of Loan } & $\begin{array}{c}\text { Percentage of } \\
\text { total } \\
\text { Observations }\end{array}$ & \multicolumn{1}{|c|}{ Use of Loan } & $\begin{array}{c}\text { Percentage of total } \\
\text { Observations }\end{array}$ \\
\hline Buy Property & $10.63 \%$ & Tailor & $5 \%$ \\
\hline Education & $1.88 \%$ & Fabric & $3.75 \%$ \\
\hline Marriage and Education & $0.63 \%$ & Restaurant & $1.88 \%$ \\
\hline Marriage & $15.63 \%$ & Parlor & $2.50 \%$ \\
\hline Buy stocks & $3.13 \%$ & Save & $1.25 \%$ \\
\hline Buy Equiment & $3.13 \%$ & Cushions & $1.25 \%$ \\
\hline
\end{tabular}




\begin{tabular}{|l|c|l|l|} 
Furniture Business & $0.63 \%$ & Handicraft & $1.25 \%$ \\
\hline Shop (Retainling) & $11.25 \%$ & Property Dealer & $0.63 \%$ \\
\hline Tea Stall & $1.88 \%$ & Dry/Clean & $3.13 \%$ \\
\hline Tea/Food & $13.88 \%$ & $\begin{array}{l}\text { Sharperner } \\
\text { Business }\end{array}$ & $0.63 \%$ \\
\hline Rickshaw & $3.75 \%$ & Socks Business & $0.63 \%$ \\
\hline Work shops & $6.25 \%$ & Kabari & $0.63 \%$ \\
\hline Street Hawker & $1.25 \%$ & Garderner & $0.63 \%$ \\
\hline Van/Bus & $1.88 \%$ & Shoe Repair & $0.63 \%$ \\
\hline Poultry Farm & $1.25 \%$ & School & $0.63 \%$ \\
\hline NGO & $0.63 \%$ & Lottery & $0.63 \%$ \\
\hline
\end{tabular}

Table 4: Loan use in various sectors

Source: Author's calculations.

\begin{tabular}{|l|l|}
\hline Sector & Percentages \\
\hline Service & $28.75 \%$ \\
\hline Retail & $30.00 \%$ \\
\hline Wholesale & $5.00 \%$ \\
\hline Manufacturing & $0.63 \%$ \\
\hline Household & $35.63 \%$ \\
\hline
\end{tabular}

It is observed that the highest amount of loans, 35\%, was used for household purposes such as consumption smoothing, or marriages. This is followed by retailing. Hence, most of the micro loans are not used for investment purposes. This problem has already been identified by various authors ${ }^{1}$. However, this study shows that there are potential recipients out there, and the number is growing steadily, who want to invest the loans in micro businesses. In the previous table, it is seen that $15 \%$ loans are being used for marriage purposes followed by $11 \%$, which is going for shops, defined here as general stores at a very small level.

\section{Analysis of data}

As explained above, this section focuses on analysis of the data collected for 160 households. Firstly, we present the summary of microfinance recipients' preferences for loan levels and their choice of interest rates. Higher loan amounts are comparatively lesser in demand. But demand for that loan increases as the repayment period doubles, also pointed out in a study by Karlan and Zinman (2006) that recipients are more sensitive to changes in repayment rates (compare the demand for loan of Rs 40000 and Rs 40000 at 2 years).

Table 5: Willingness to Pay at Different Loan Levels

Source: Author's calculations.

\begin{tabular}{|l|r|r|r|r|r|r|r|}
\hline & \multicolumn{7}{|c|}{ Interest Rates Offered } \\
\hline $\begin{array}{l}\text { Loan Levels } \\
\text { PKR) }\end{array}$ & $\mathbf{5 \%}$ & $\mathbf{1 0 \%}$ & $\mathbf{1 5 \%}$ & $\mathbf{2 0 \%}$ & $\mathbf{2 5 \%}$ & $\mathbf{3 0 \%}$ & Total \\
\hline $\mathbf{5 0 0 0}$ & 3 & 9 & 4 & 15 & 8 & 119 & 158 \\
\hline $\mathbf{1 0 0 0 0}$ & 9 & 8 & 8 & 30 & 10 & 78 & 143 \\
\hline $\mathbf{1 5 0 0 0}$ & 8 & 12 & 14 & 30 & 7 & 52 & 123 \\
\hline $\mathbf{2 0 0 0 0}$ & 7 & 13 & 8 & 28 & 5 & 32 & 93 \\
\hline $\mathbf{2 5 0 0 0}$ & 10 & 10 & 2 & 12 & 2 & 24 & 60 \\
\hline $\mathbf{3 0 0 0 0}$ & 4 & 6 & 6 & 8 & 0 & 17 & 41 \\
\hline $\mathbf{4 0 0 0 0}$ & 3 & 1 & 0 & 2 & 1 & 10 & 17 \\
\hline $\mathbf{4 0 0 0 0}(\mathbf{2}$ years) & 5 & 2 & 1 & 22 & 5 & 18 & 53 \\
\hline
\end{tabular}

${ }^{1}$ See, e.g., "Issues in Pakistan Economy" by S. Akbar Zaidi 


\section{\begin{tabular}{|l|r|r|r|r|r|r|r|} 
Above 40000 & 14 & 9 & 1 & 30 & 5 & 52 & 111 \\
\hline
\end{tabular}}

Theoretically, the demand for loan size should fall as the interest rate increases. It is also believed that microfinance recipients are interest-inelastic. The table below shows the overall average willingness to pay at different loan levels. As loan levels increase, average willingness to pay falls.

Table 6: Maximum Average Willingness to Pay at Different Loan Levels

Source: Author's calculations.

\begin{tabular}{|c|c|}
\hline Loan Levels & Avg. WTP \\
\hline 5000 & 26.8 \\
\hline 10000 & 24.02 \\
\hline 15000 & 21.9 \\
\hline 20000 & 20.75 \\
\hline 25000 & 19.8 \\
\hline 30000 & 20.48 \\
\hline 40000 & 22.9 \\
\hline $40000(2 \mathrm{yr})$ & 21.98 \\
\hline
\end{tabular}

Our study however doesn't confirm the view that recipients are interest-elastic. In fact, a mixed picture is seen. Following table shows that, for any loan size, number of recipients fluctuates as interest rate increases. While number of recipients falls as interest rates increases from $20 \%$ to $25 \%$, it rises significantly when the interest rate increases to $30 \%$, especially for lower loan levels, which typically represent a microloan.

Table 7: Interest Elasticity of Demand for Microloans

Source: Author's calculations.

\begin{tabular}{|l|r|r|r|r|r|r|}
\cline { 2 - 7 } \multicolumn{1}{c|}{} & \multicolumn{7}{|c|}{ Interest Rates Offered } \\
\hline $\begin{array}{l}\text { Loan Levels } \\
\text { (PKR) }\end{array}$ & $\mathbf{5 \%}$ & $\mathbf{1 0 \%}$ & $\mathbf{1 5 \%}$ & $\mathbf{2 0 \%}$ & $\mathbf{2 5 \%}$ & $\mathbf{3 0 \%}$ \\
\hline $\mathbf{5 0 0 0}$ & - & 1.2 & -1 & 2.2 & -1.4 & 22.2 \\
\hline $\mathbf{1 0 0 0 0}$ & - & -0.2 & 0 & 4.4 & -4 & 13.6 \\
\hline $\mathbf{1 5 0 0 0}$ & - & 0.8 & 0.4 & 3.2 & -4.6 & 9 \\
\hline $\mathbf{2 0 0 0 0}$ & - & 1.2 & -1 & 4 & -4.6 & 5.4 \\
\hline $\mathbf{2 5 0 0 0}$ & - & 0 & -1.6 & 2 & -2 & 4.4 \\
\hline $\mathbf{3 0 0 0 0}$ & - & 0.4 & 0 & 0.4 & -1.6 & 3.4 \\
\hline $\mathbf{4 0 0 0 0}$ & - & -0.4 & -0.2 & 0.4 & -0.2 & 1.8 \\
\hline $\mathbf{4 0 0 0 0}$ (2 years) & - & -0.6 & -0.2 & 4.2 & -3.4 & 2.6 \\
\hline
\end{tabular}

\subsection{WTP According to Actual and Potential Microfinance recipients'}

The survey was taken from both potential and actual customers of micro loans. Tables 8 and 9 (Appendix A) show the results. The average willingness to pay and the quantity of loans purchased are higher for lower loan levels as compared to higher loan levels in general for both types of recipients. The potential customers, however, are willing to pay slightly higher on average than the actual customers but the difference is not significant. The average willingness to pay, especially for the first four loan categories (ranging from $21 \%$ to $27 \%$ ) is almost the same for both groups of customers, which also implies that the sample of 'potential microfinance recipients' is an authentic source to find out maximum willingness to pay. Actual microfinance recipients are paying low for loan levels of Rs. 25000 onwards but their willingness to pay increases if the loan repayment period is increased. The fact that potential microfinance recipient is willing to pay slightly higher amount could be attributed to the fact that actual customers have already faced the administrative procedures of borrowing and securing a loan and thus, are not willing to buy a large amount of loans. However, the idea is new and interesting from the potential customer prospective.

\subsection{WTP According to Income levels}

The data is divided into five distinct categories of income levels: $1000<$ Income $\leq 5000,5000<$ Income $\leq 10000,10000<$ Income $\leq 15000,15000<$ Income $\leq 20000$ and Income $>20000$. Across these income levels, one would expect the loan amounts bought to increase. The total amounts of loan taken are 19, 206 and 
271 for first 3 income categories respectively. For income levels higher than PKR15000, the amounts of loans taken fall to around 96.

For the lowest income category of PKR 1000 - PKR 5000, number of loans is very low as people's ability to pay is lower, although average willingness to pay is high. More loan amounts are purchased by recipients of higher income category of PKR 5000 - PKR10000 because they are willing and able to do so. The interest rates at which the loans are purchased are higher for lower loan amounts, the result that is consistent with the previous income category. However, as loan levels increase, average willingness to pay falls. The most popular income category is PKR 10000 - PKR 15000. People are willing to purchase every loan level at higher interest rates. The willingness to pay doesn't fall below $20 \%$ for any category or for any given loan repayment period. These people demand more loans as they are in dire need of money for initiating or expanding their businesses. The income category of PKR 15000 and above represents relatively less poor people whose monthly expenditures are between PKR 15, 000 and PKR 20, 000. Such recipients demand fewer amounts of loans because they either don't have any micro level business or they have alternative sources of income. Similar argument can be used to explain the trend of microloans demanded and average willingness to pay for the income category of greater than PKR 20000.

\subsection{WTP According to Head of Household:}

Tables 15 to 19 (Appendix A) show that in majority of the cases, the household head is a man, who could be a father, a spouse or a brother. In few cases, women who had taken the loan themselves were the head while the rest of the households in the survey had 'joint', i.e. both husband and wife, as decision makers. The total amounts of loans taken, regardless of the loan size, are significantly higher when the head of household is a man (more than 160 as opposed to only 56 where household head is female). However, interestingly, if both woman and the spouse were jointly heading the households, the amounts of loan taken were the highest: 223 . Hence, men seemed to have more control over the decisions of whether to take a loan or not and where to invest. As expected, the demand for loan across loan levels fell as the size of loans increased. The average willingness to pay for different categories of household heads is not forming any distinct pattern but in most cases, willingness to purchase exceeds $20 \%$.

\subsection{WTP According to Proportion of Children or Sibling Educated}

The incidence of education in the low-income households was not significant. However, certain people wanted to educate their children for a better future and hence, wanted higher loan amounts. We see how loan demand varied across the categories of 'none of the children or siblings educated in a household', 'partly educated' and 'all of them getting the education'. The results, shown in Appendix 'A', tables 20 to 22 respectively show that people are willing to take more loans if at least some of the siblings and children are educated in a household. Parents may want their children, who had already started their education, to continue attaining higher education levels even in the face of possible future income constraints or they may want more money for educating other children and/or sibling. On the other hand, they may demand loan for other purposes highlighted in Table 4 in the previous section. The demand for microloans falls slightly if every sibling and children of the potential or actual loan taker is getting the education, i.e. the proportion of the people in a household educated is equal to 1 . Hence, it is generally observed that education is affecting the loan demand positively, although the affect is moderate. It is also identified that on average, the maximum willingness to pay for a microloan increases for the same loan size, as more people get educated in the household, highlighting the inelastic demand faced by such borrowers.

\subsection{WTP According to loan Investment}

Broadly speaking, the use of loan can be divided into two categories: productive and non-productive. People could expand or start their businesses or use the money for marrying their children or buying a new lowpriced house. The number of households that wanted to start a business exceeded those who wanted to expand their established business (compare Business (Table 23) and Expand Business (Table 27)). The amount of loan equal to PKR 40000 can be helpful for kick-starting the smalls scale businesses and as there is certainty of future income that could be used for paying the loan back, the loan demand is higher for such households. Also, it is observed that willingness to pay is as high as $30 \%$, with the average of more than $22 \%$, for those who wanted to expand their established business. On the other hand, those who wanted to start a business had comparatively lower willingness to pay. For 'Marriage' and 'Other' non-productive uses of borrowed loans, the demand is comparatively lower although the willingness to pay for such loans is equally high because of inelastic nature of demand for the product.

It can be concluded from the analysis that loan should be disbursed to households whose monthly incomes are between PKR 10000 and PKR 15000, with moderate education levels, 'joint' household heads and where the loan is taken for expanding an established business. They demand high loan amounts and also 
generally are seen to be able to accept higher interest rates. But which of these variables are more important for specific loan levels? The next section answers this question.

\section{Model Estimation and Results}

The willingness to pay for a particular loan level is considered to be a function of number of factors such as monthly income, expenditures, savings, sector of loan investment, incidence of education in the household, and so on. The table below shows the results of the loan-specific econometric analysis for the four most popular loan levels: Rs. 5000, Rs. 10,000, Rs. 15,000 and Rs. 20,000.

The dependent variable is defined as a binary variable taking values of ' 1 ' if the respondent answered an interest rate level of $20 \%, 25 \%$ and $30 \%$, and ' 0 ' otherwise, i.e. $5 \%, 10 \%$ or $15 \%$. For a limited dependent variable analysis, binary logit regression had been chosen under which the probability of getting ' 1 ' for the dependent variable or the probability of paying a higher interest rate at various loan levels depended on 'vector of observed covariates'.

Before the results are discussed, it would be useful to describe the explanatory variables. Most of them are self-explanatory such as 'Age', 'Expenditure, income and savings per month', etc. The following table explains the dummy regressors only. The loans taken could be invested in small businesses such as a 'parlor' or setting up a 'tea stall'. Such loan uses were categorized as being part of either a 'Retail Sector', or a 'Wholesale Sector', or 'Services'. Some loan amounts were demanded for purchasing a bigger house that could be used for renting purposes or towards small scale industrial sector. This category was named as 'OTHER', and was dropped among the four dummies.

Table 29: Explanation of Variables for Econometric Analysis

\begin{tabular}{|l|l|l|}
\hline Variable & Explanation \\
\hline Gender & Female Loantaker =1 & Male $=0$ \\
\hline Marital Status & Married =1 & Unmarried $=0$ \\
\hline Household Head & Female: 1 & Joint: 0 \\
\hline Female employment dummy & Female Emp.: 1 & Otherwise: 0 \\
\hline Preference of Micro-saving account & Yes: 1 & Otherwise: 0 \\
\hline If loan taker wants to take loan individually & Yes: 1 & No: 0 \\
\hline Retail Sector Dummy & Retail: 1 & Otherwise: 0 \\
\hline Wholesale Sector Dummy & Wholesale: 1 & Otherwise: 0 \\
\hline Services Dummy & Service: 1 & Otherwise: 0 \\
\hline
\end{tabular}

Table 30: Binary Logit Model Results Across Loan Amounts

\begin{tabular}{|c|c|c|c|c|}
\hline $\begin{array}{l}\text { Dependent } \\
\text { Variable: }\end{array}$ & \begin{tabular}{|c} 
Willingness to Pay \\
for Rs 5000; Less \\
than $15 \%=0,20 \%$, \\
$25 \%$ or $30 \%: 1$
\end{tabular} & $\begin{array}{c}\text { Willingness to Pay } \\
\text { for Rs } 10000 \text { Less } \\
\text { than } 15 \%=0,20 \% \text {, } \\
25 \% \text { or } 30 \%: 1\end{array}$ & $\begin{array}{c}\text { Willingness to Pay } \\
\text { for Rs 15000; Less } \\
\text { than } 15 \%=0,20 \% \text {, } \\
25 \% \text { or } 30 \%: 1\end{array}$ & \begin{tabular}{|c} 
Willingness to Pay \\
for Rs 20000; Less \\
than $15 \%=0,20 \%$, \\
$25 \%$ or $30 \%: 1$
\end{tabular} \\
\hline & \begin{tabular}{|l|} 
Coefficient \\
\end{tabular} & \begin{tabular}{|l|} 
Coefficient \\
\end{tabular} & \begin{tabular}{|l|} 
Coefficient \\
\end{tabular} & \begin{tabular}{|l|} 
Coefficient \\
\end{tabular} \\
\hline constant & $\begin{array}{c}5.279 \\
(2.427628)\end{array}$ & $\begin{array}{c}3.544540 \\
(1.674599)\end{array}$ & $\begin{array}{c}2.493072 \\
(1.257891)\end{array}$ & $\begin{array}{l}30.06403 \\
() 2.439956\end{array}$ \\
\hline Age & $\begin{array}{c}-0.040 \\
(-1.296008)\end{array}$ & $\begin{array}{c}0.003188 \\
(0.117157)\end{array}$ & $\begin{array}{l}-0.010856 \\
(-0.300601)\end{array}$ & $\begin{array}{l}\mathbf{0 . 2 9 2 9 7 4} * \\
(1.732917)\end{array}$ \\
\hline $\begin{array}{l}\text { Marital Status } \\
\text { Dummy }\end{array}$ & $\begin{array}{c}-0.490 \\
(-0.395977) \\
\end{array}$ & $\begin{array}{l}-1.646886 \\
(-0.822600) \\
\end{array}$ & $\begin{array}{c}\mathbf{- 3 . 0 3 1 9 3 8 * * * *} \\
(-3.044387) \\
\end{array}$ & $\begin{array}{l}-\mathbf{1 2 . 1 0 6 5 9 * *} \\
(-2.146968)\end{array}$ \\
\hline Gender Dummy & $\begin{array}{c}-1.283 \\
(-0.851919)\end{array}$ & $\begin{array}{c}0.052844 \\
(0.056413)\end{array}$ & $\begin{array}{c}-0.198770 \\
(-0.247081)\end{array}$ & $\begin{array}{c}\mathbf{- 7 . 3 2 6 0 3 4} * * * * \\
(-2.769327)\end{array}$ \\
\hline $\begin{array}{l}\text { Expenditure per } \\
\text { month (PKR) }\end{array}$ & $\begin{array}{l}-3.19 \mathrm{E}-05 \\
(-0.698639)\end{array}$ & $\begin{array}{l}1.23 \mathrm{E}-05 \\
(0.256544)\end{array}$ & $\begin{array}{l}-\mathbf{- 0 . 0 0 0 3 7 3 * *} \\
(-1.929193)\end{array}$ & $\begin{array}{l}\mathbf{- 0 . 0 0 0 5 2 1 *} \\
(-1.864769)\end{array}$ \\
\hline $\begin{array}{l}\text { Monthly Savings } \\
\text { (PKR) }\end{array}$ & $\begin{array}{c}-0.000275 \\
(-0.626799)\end{array}$ & $\begin{array}{c}-0.000156 \\
(-0.728769)\end{array}$ & $\begin{array}{c}0.000321 \\
(0.866394)\end{array}$ & $\begin{array}{c}0.001610 \\
(1.185223)\end{array}$ \\
\hline $\begin{array}{l}\text { Income Per Month } \\
\text { (PKR) }\end{array}$ & $\begin{array}{c}0.000133 \\
(1.571834)\end{array}$ & $\begin{array}{c}1.23 \mathrm{E}-05 \\
(0.156049) \\
\end{array}$ & $\begin{array}{l}\mathbf{0 . 0 0 0 3 0 2} * \\
(1.817467) \\
\end{array}$ & $\begin{array}{l}\mathbf{0 . 0 0 1 0 5 6 * * * *} \\
(2.903995)\end{array}$ \\
\hline \begin{tabular}{|l|} 
Female \\
Employment \\
Dummy
\end{tabular} & $\begin{array}{c}-0.315 \\
(-0.335640)\end{array}$ & $\begin{array}{c}-0.277468 \\
(-0.288466)\end{array}$ & $\begin{array}{c}-0.644987 \\
(-0.704828)\end{array}$ & $\begin{array}{c}6.163472 \\
(1.327944)\end{array}$ \\
\hline
\end{tabular}




\begin{tabular}{|c|c|c|c|c|}
\hline Household Head & $\begin{array}{l}\text { 38.113*** } \\
(40.53723)\end{array}$ & $\begin{array}{c}\text { 38.60726**** }^{*} \\
(41.58556)\end{array}$ & $\begin{array}{c}-1.372188 \\
(-1.432630)\end{array}$ & $\begin{array}{l}\mathbf{- 2 . 1 0 9 1 7 4} * \\
(-1.650952)\end{array}$ \\
\hline $\begin{array}{l}\text { Total size of } \\
\text { household }\end{array}$ & $\begin{array}{c}-0.189 \\
(-1.262164)\end{array}$ & $\begin{array}{c}-0.082118 \\
(-0.661583)\end{array}$ & $\begin{array}{c}0.115837 \\
(0.749559)\end{array}$ & $\begin{array}{c}-0.918858 \\
(-1.245235)\end{array}$ \\
\hline $\begin{array}{l}\text { Proportion of } \\
\text { household } \\
\text { educated }\end{array}$ & $\begin{array}{c}0.809 \\
(0.662258) \\
\end{array}$ & $\begin{array}{c}-0.025552 \\
(-0.032089)\end{array}$ & $\begin{array}{c}-1.019000 \\
(-0.919957)\end{array}$ & $\begin{array}{l}\mathbf{- 3 . 4 9 8 3 4 7 *} \\
(-1.685764)\end{array}$ \\
\hline $\begin{array}{l}\text { Proportion of } \\
\text { household } \\
\text { employed }\end{array}$ & $\begin{array}{c}0.140 \\
(0.106835) \\
\end{array}$ & $\begin{array}{c}0.806134 \\
(0.363716)\end{array}$ & $\begin{array}{c}-0.277365 \\
(-0.091333) \\
\end{array}$ & $\begin{array}{c}\mathbf{- 3 4 . 7 1 6 4 4 * *} \\
(-2.402380)\end{array}$ \\
\hline $\begin{array}{l}\text { Interaction } \\
\text { dummy (Gender } \\
\text { and Household } \\
\text { head) }\end{array}$ & $\begin{array}{c}38.96 * * * \\
(33.27853) \\
\end{array}$ & $\begin{array}{c}-0.438919 \\
(-0.420612) \\
\end{array}$ & $\begin{array}{c}-1.142422 \\
(-1.281956) \\
\end{array}$ & $\begin{array}{c}\mathbf{3 7 . 5 5 1 5 7} * * * \\
(14.42513) \\
\end{array}$ \\
\hline $\begin{array}{l}\text { Interaction } \\
\text { dummy (Gender } \\
\text { and Female } \\
\text { Employment } \\
\text { Dummy) }\end{array}$ & $\begin{array}{c}0.950 \\
(0.369723) \\
\end{array}$ & $\begin{array}{c}-0.543640 \\
(-0.490377)\end{array}$ & $\begin{array}{c}1.059501 \\
(1.011265) \\
\end{array}$ & $\begin{array}{l}\mathbf{- 3 . 6 6 6 0 1 2} * \\
(-1.668765)\end{array}$ \\
\hline $\begin{array}{l}\text { Individual loan } \\
\text { taker Dummy }\end{array}$ & $\begin{array}{c}-0.293 \\
(-0.468978) \\
\end{array}$ & $\begin{array}{c}-0.415429 \\
(-0.493891)\end{array}$ & $\begin{array}{l}1.202721^{*} \\
(1.672304) \\
\end{array}$ & $\begin{array}{c}\mathbf{- 9 . 0 7 3 2 5 5} * * \\
(-2.379058) \\
\end{array}$ \\
\hline $\begin{array}{l}\text { Preference for } \\
\text { Micro-saving } \\
\text { account Dummy }\end{array}$ & $\begin{array}{c}-0.358 \\
(-0.378542) \\
\end{array}$ & $\begin{array}{c}-1.090815 \\
(-1.533222) \\
\end{array}$ & $\begin{array}{c}0.860192 \\
(1.191565) \\
\end{array}$ & $\begin{array}{c}\mathbf{4 . 5 8 0 6 7 4 * *} \\
(2.361854) \\
\end{array}$ \\
\hline Cost of Production & $\begin{array}{c}-2.02 \mathrm{E}-06 \\
(-0.294819) \\
\end{array}$ & $\begin{array}{c}7.60 \mathrm{E}-06 \\
(1.166756) \\
\end{array}$ & $\begin{array}{c}-8.98 \mathrm{E}-06 \\
(-0.873618) \\
\end{array}$ & $\begin{array}{c}-7.00 \mathrm{E}-05 \\
(-1.565836) \\
\end{array}$ \\
\hline Retail Dummy & $\begin{array}{c}0.831 \\
(1.132886)\end{array}$ & $\begin{array}{l}\mathbf{2 . 4 7 6 2 7 2 *} \\
(1.677237)\end{array}$ & $\begin{array}{c}\mathbf{3 . 1 6 9 3 6 2} * * * \\
(3.519335)\end{array}$ & $\begin{array}{c}-0.998764 \\
(-0.827479) \\
\end{array}$ \\
\hline Service Dummy & $\begin{array}{c}1.736 \\
(0.999201) \\
\end{array}$ & $\begin{array}{c}1.089911 \\
(1.365163) \\
\end{array}$ & $\begin{array}{c}\mathbf{1 . 7 7 8 0 9 1} * * \\
(1.971003)\end{array}$ & $\begin{array}{c}-1.186523 \\
(-0.958174) \\
\end{array}$ \\
\hline $\begin{array}{l}\text { Wholesale } \\
\text { Dummy }\end{array}$ & $\begin{array}{c}-1.150 \\
(-0.654104)\end{array}$ & $\begin{array}{l}\mathbf{- 2 . 1 3 0 6 1 2} * \\
(-1.795471) \\
\end{array}$ & $\begin{array}{c}0.655515 \\
(0.529294)\end{array}$ & $\begin{array}{c}-10.50538 \\
(-1.489895) \\
\end{array}$ \\
\hline
\end{tabular}

Notes: z-stats are given in parentheses; $*, * *$, and $* * *$ indicate significance at 10,5 , and 1 percent, respectively. Source: Author's calculations.

Results show that for the loan level of Rs. 5000, household demographics are not statistically important in explaining the willingness to pay high interest rates. However, it is noticed that if the loan taker is a female AND the household head, she would be willing to pay a higher interest rate for this loan level. This can be attributed to the inelastic demand of the loan which can be used for solving cash constraints in an established small scale business.

For the loan amount of Rs 10,000, again, loan takers with female household heads should be targeted because they are willing to pay $20 \%$ or above. Also, it can be seen that if the loan is invested in a retail sector, which may include small shops of eatables, the probability of willing to pay a more than $15 \%$ interest rate significantly increases whereas the effect is opposite and significant if the variable of 'Wholesale Dummy' is observed. This difference can be attributed to the fact that Retail sector is perceived to have more profitable opportunities than Wholesale sector.

Gender doesn't play any significant part in the case of the loan level of Rs. 15, 000. As expected, for a higher loan amount, variables like Income and Expenditures become important in determining the willingness to pay a higher interest rate. If income is high, willingness to pay should increase while higher expenditures would propel the loan taker to pay a lower interest rate of either $15 \%$ or even less than that. Loan takers were not comfortable in buying bigger loan amounts in groups as members could not be trusted. Hence, if the loan is taken individually, the probability of paying a higher loan price increases. If the loan taker is married, willingness to pay a higher loan price falls probably because the certainty of enough income generation in future is low. As explained for the previous loan level, since retail and services sectors have more profitable investment opportunities, the associated signs for Rs 15, 000 are positive and significant in explaining the higher willingness to pay.

For the loan level of Rs 20, 000, variables of 'Income, Expenditure and Marital Status' have the same effect as for Rs 10,000, and they are significant as well. The effect of other variables cannot be compared with previous regression results. If the loan-taker is a female and is also acting as the household head, the willingness 
to pay a high loan price, which exceeds $15 \%$, significantly goes up. On the other hand, an employed female loan taker is willing to pay a lower price for the loan because such high loan levels don't have an inelastic demand for employed people. This is supported by the fact that when more of the people in a household are employed, the willingness to pay a higher interest rate significantly falls, as they have already different sources of income in a household. Lastly, these loan levels are directed towards 'small scale industrial sector' as that is conceived to be much more profitable and useful.

\section{Random Effects Model}

Further analysis of the data tested the factors that are significant in increasing the willingness to pay across the four loan levels. For that, a panel data analysis was run whereby four most demanded loan levels were taken: PKR5000, PKR10000, PKR15000 and PKR 20000. It was observed that in general, female customers are willing to pay high interest rates at any loan level as shown in the following table. Also, if customers had already taken a micro loan from formal or informal sectors, the willingness to pay would increase. This highlights the fact that "loan-takers" are firstly more aware of the loan taking procedures and if they are buying a loan again, this indicates that their previous loan turned out to be productive and useful. Another variable that may attract the micro finance institutions because of their higher willingness to pay for the loan is the saving pattern of the customers. Higher 'savings' will be a source of income that can be used for paying back the installments in a timely manner even if any emergency occurs and thus, more savings will raise the willingness to buy the loan at a higher interest rate.

Other variables are not significantly indicating any change in the willingness to pay for the micro loans. Therefore, it is recommended that loans should be directed towards females who have already purchased a loan and have strong savings pattern.

Table 31: Random Effects Model (Panel Data Analysis)

\begin{tabular}{|c|c|}
\hline Variables & Coefficient \\
\hline Gender & $\begin{array}{l}\mathbf{0 . 3 5} * * * * \\
(2.43)\end{array}$ \\
\hline Interaction dummy (Gender and Household head) & $\begin{array}{l}-0.398 \\
(-0.56)\end{array}$ \\
\hline Age & $\begin{array}{l}-0.000015 \\
(-0.02)\end{array}$ \\
\hline Marital Status Dummy & $\begin{array}{l}-0.0075 \\
(-0.36)\end{array}$ \\
\hline Total size of household & $\begin{array}{l}0.0023 \\
(0.99)\end{array}$ \\
\hline Household Head & $\begin{array}{l}0.023 \\
(0.35)\end{array}$ \\
\hline Income Per Month (PKR) & $\begin{array}{l}0.0000013 \\
(0.76)\end{array}$ \\
\hline Expenditure per month (PKR) & $\begin{array}{l}0.000000381 \\
(0.32)\end{array}$ \\
\hline Monthly Savings (PKR) & $\begin{array}{l}0.00000632 \\
(1.09)\end{array}$ \\
\hline $\begin{array}{l}\text { Interaction dummy (Gender and Female } \\
\text { Employment Dummy) }\end{array}$ & $\begin{array}{l}-0.027 \\
(-0.82) \\
\end{array}$ \\
\hline Female Employment Dummy & $\begin{array}{l}0.0115 \\
(0.39)\end{array}$ \\
\hline Proportion of household employed & $\begin{array}{l}0.0046 \\
(0.12)\end{array}$ \\
\hline Proportion of household educated & $\begin{array}{l}0.000631 \\
(0.04)\end{array}$ \\
\hline Preference for Micro-saving account Dummy & $\begin{array}{l}0.0043 \\
(0.37)\end{array}$ \\
\hline Services Dummy & $\begin{array}{l}-0.0086 \\
(-0.52)\end{array}$ \\
\hline Retail Dummy & $\begin{array}{l}0.009 \\
(0.58)\end{array}$ \\
\hline
\end{tabular}




\begin{tabular}{|l|l|}
\hline Wholesale Dummy & $\begin{array}{l}-0.012 \\
(-0.48)\end{array}$ \\
\hline Cost of Production & $\begin{array}{l}4.41 \mathrm{e}-08 \\
(0.24)\end{array}$ \\
\hline Individual loan taker Dummy & $\begin{array}{l}0.0065 \\
(0.52)\end{array}$ \\
\hline Loan already taken (1 if Yes) & $\mathbf{0 . 0 2 5} *$ \\
$(1.64)$
\end{tabular}

Notes: $\mathrm{z}$-stats are given in parentheses; $*, * *$, and $* * *$ indicate significance at 10,5 , and 1 percent, respectively. Source: Author's calculations.

\section{Conclusion and Policy Implications}

For any sustainable and financially independent microcredit program, setting high interest rates are crucial. Microfinance recipients' willingness to accept an interest rate may differ for different loan amounts. According to our study, it can be seen in Table 7 above, that maximum average willingness to pay for any given loan levels is different. For example, it can be observed that if interest rate is set at $26 \%$, low income households would demand Rs 5000 only while at the interest rate of $22 \%$, they can afford to purchase loans of Rs 15000 . Hence, it is rather suggested that setting loan-amount specific interest rates or case-specific interest rates can be more beneficial for the institutions rather than a standard rate and that ALL borrowers are interest-inelastic or interest-elastic is not supported. People will demand higher levels of loan at lower interest rate, but the interest rate does not have to fall by a huge amount to attract people for purchasing higher loan amounts. Also, numbers of people buying a particular loan level respond more to changes in repayment period rather than changes in interest rates.

It is obvious that case specific interest rate policy would raise the transaction costs. Hence, if standard rate policy is preferred, then loans should be given to carefully chosen households. For that, we also examined the factors that increased the willingness to pay (above or at 20\%) for most popular loan levels: PKR 5000 PKR 20000. It was observed that for different loan levels, factors differed. Female loan takers who are also household heads or loan takers with female household head are generally willing to pay high interest rate for loan PKR 5000 and PKR 10,000, particularly because in the absence of any collateral and missing labor market and in order to prove their creditworthiness, they accept higher interest rates on nominal loan sizes. Relatively higher loan levels of PKR 15000 - PKR 20000 should particularly target the households with higher income, low expenditure and higher savings where household residents are not interested in getting employed anywhere or getting educated (as they run and focus only on their own business at small scale). Lower loan categories are demanded for retail or services sector whereas higher categories are consumed in small scale industrial sector.

This study establishes pathway to optimal allocation of loans amongst the interested microfinance applicants. The microfinance institution can set a standard 'high' interest rate but the optimal type of recipients differs for different loan levels.

\section{References}

[1] S. A. Rauf and T. Mahmood, Growth and Performance of Microfinance in Pakistan, Pakistan Economic and Social Review, Volume 47, No. 1, 2009, pp. 99-122

[2] A. N. Fernando, Understanding and Dealing with High Interest Rates on Microcredit, A Note to Policy Makers in the Asia and Pacific Regions, 2006, Asian Development Bank

[3] R. Sengupta and P. C. Aubuchon, The Microfinance Revolution: An Overview, Federal Reserve Bank of St. Louis Review, 90(1), 2008, , pp. 9-30.

[4] A. G. Ayayi, and M. Sene, What Drives Microfinance Institution's Financial Sustainability, The Journal of Developing Areas, Nashville, Vol. 44, Issue 1, (2010), pg. 303, 22 pgs

[5] A. Khan, Tackling the failure of microfinance efforts through amalgamating microfinance with charity: two viable alternatives in the context of Pakistan, Australasian Accounting Business and Finance Journal, Volume 2, Issue 2, 2008

[6] D. Karlan and J. Zinman, Elasticities of Demand for Consumer Credit, Yale University Economic Growth Center, Center Discussion Paper No. 926, 2006

[7] E. Duflo, A. Banerjee, R. Glennester and C. Kinnan, C, The miracle of microfinance? Evidence from a randomized evaluation, Working Paper, 2009

[8] J. Morduch, R. Cull and A. Demirguc-Kunt, Microfinance meets the Market, Journal of Economic Prospectives, 23 (1), Winter, 2009, $167-192$

[9] X. Giné and D. Karlan, Group versus Individual Liability: Evidence from a Field Experiment in the Philippines, Yale University Economic Growth Center working paper 940, 2008

[10] E. Field and R. Pande, Repayment Frequency and Default in Micro-Finance: Evidence from India. Journal of European Economic Association 6:2-3, 2008, pp. 501-509

[11] F. Erica and P. Rohini, Repayment Frequency and Default in Microfinance: Evidence from India, Journal of European Economic Association, Volume 6, Issue 2-3, 2008, pages 501-509

[12] S. Shankar, Transaction costs in group Microcredit in India, Management Decision, Vol. 45 No. 8, 2007, pp. 1331-1342 
[13] J. Morduch, R. Dehejia and H. Montgomery, Do Interest Rates Matter? Credit Demand in the Dhaka Slums, Working Paper, NYU, 2005

[14] A.K.M. Morshed, M. Emran and J. E. Stiglitz, Microfinance and Missing Markets, Unpublished manuscript, October 2006

Appendix A

Source: Author's calculations.

Table 8: WTP by Potential Customers

\begin{tabular}{|c|c|c|c|c|c|c|c|c|}
\hline $\begin{array}{l}\text { Loan } \\
\text { Levels }\end{array}$ & $30 \%$ & $25 \%$ & $20 \%$ & $15 \%$ & $10 \%$ & $5 \%$ & Totals & AMWTP \\
\hline 5000 & 62 & 5 & 6 & 2 & 3 & 2 & 80 & $27.19 \%$ \\
\hline 10000 & 40 & 7 & 15 & 4 & 3 & 5 & 74 & $24.19 \%$ \\
\hline 15000 & 28 & 4 & 15 & 8 & 5 & 3 & 63 & $22.62 \%$ \\
\hline 20000 & 18 & 2 & 16 & 4 & 5 & 1 & 46 & $22.28 \%$ \\
\hline 25000 & 15 & 1 & 4 & 1 & 3 & 4 & 28 & $22.14 \%$ \\
\hline 30000 & 12 & 0 & 4 & 2 & 0 & 1 & 19 & $25.00 \%$ \\
\hline 40000 & 7 & 1 & 1 & 0 & 0 & 0 & 9 & $28.33 \%$ \\
\hline $\begin{array}{l}40000 @ \\
2\end{array}$ & 8 & 3 & 11 & 0 & 1 & 1 & 24 & $22.92 \%$ \\
\hline Totals & 224 & 24 & 87 & 22 & 22 & 22 & 401 & \\
\hline
\end{tabular}

Table 9: WTP by Actual Customers

\begin{tabular}{|l|l|l|l|l|l|l|l|l|}
\hline Loan Levels & $\mathbf{3 0 \%}$ & $\mathbf{2 5 \%}$ & $\mathbf{2 0 \%}$ & $\mathbf{1 5 \%}$ & $\mathbf{1 0 \%}$ & $\mathbf{5 \%}$ & Totals & AMWTP \\
\hline 5000 & 30 & 1 & 5 & 1 & 3 & 0 & 40 & $26.75 \%$ \\
\hline 10000 & 23 & 1 & 8 & 1 & 2 & 0 & 35 & $26.00 \%$ \\
\hline 15000 & 17 & 2 & 7 & 3 & 2 & 1 & 32 & $24.06 \%$ \\
\hline 20000 & 10 & 2 & 7 & 2 & 6 & 0 & 27 & $21.48 \%$ \\
\hline 25000 & 6 & 0 & 6 & 0 & 5 & 2 & 19 & $18.95 \%$ \\
\hline 30000 & 5 & 0 & 2 & 2 & 4 & 2 & 15 & $18.00 \%$ \\
\hline 40000 & 3 & 0 & 1 & 0 & 0 & 3 & 7 & $17.86 \%$ \\
\hline $40000 @ 2$ & 6 & 2 & 6 & 0 & 0 & 1 & 15 & $23.67 \%$ \\
\hline Totals & 120 & 12 & 59 & 9 & 25 & 15 & 240 & \\
\hline
\end{tabular}

Table 10: WTP by customers earning PKR1000 to PKR5000

\begin{tabular}{|l|l|l|l|l|l|l|l|l|}
\hline Loan Levels & $30 \%$ & $25 \%$ & $20 \%$ & $15 \%$ & $10 \%$ & $5 \%$ & Totals & AMWTP \\
\hline 5000 & 7 & 0 & 0 & 0 & 0 & 0 & 7 & $30.00 \%$ \\
\hline 10000 & 3 & 0 & 0 & 0 & 0 & 1 & 4 & $23.75 \%$ \\
\hline 15000 & 1 & 0 & 1 & 0 & 0 & 2 & 4 & $15.00 \%$ \\
\hline 20000 & 0 & 0 & 2 & 0 & 0 & 0 & 2 & $20.00 \%$ \\
\hline 25000 & 0 & 0 & 0 & 0 & 0 & 0 & 0 & NA \\
\hline 30000 & 0 & 0 & 0 & 0 & 0 & 0 & 0 & NA \\
\hline 40000 & 0 & 0 & 0 & 0 & 0 & 0 & 0 & NA \\
\hline 40000 @ 2 & 1 & 0 & 1 & 0 & 0 & 0 & 2 & $25.00 \%$ \\
\hline Totals & 12 & 0 & 4 & 0 & 0 & 3 & 19 & \\
\hline
\end{tabular}

Table 11: WTP by customers earning between PKR5000 to PKR10000

\begin{tabular}{|l|l|l|l|l|l|l|l|l|}
\hline $\begin{array}{l}\text { Loan } \\
\text { Levels }\end{array}$ & $\mathbf{3 0 \%}$ & $\mathbf{2 5 \%}$ & $\mathbf{2 0 \%}$ & $\mathbf{1 5 \%}$ & $\mathbf{1 0 \%}$ & $\mathbf{5 \%}$ & Totals & AMWTP \\
\hline 5000 & 32 & 2 & 5 & 2 & 4 & 1 & 46 & $25.76 \%$ \\
\hline 10000 & 18 & 3 & 12 & 3 & 4 & 3 & 43 & $22.21 \%$ \\
\hline 15000 & 12 & 1 & 10 & 5 & 4 & 2 & 34 & $20.88 \%$ \\
\hline 20000 & 3 & 1 & 11 & 3 & 5 & 1 & 24 & $18.13 \%$ \\
\hline 25000 & 3 & 0 & 3 & 1 & 3 & 2 & 12 & $17.08 \%$ \\
\hline 30000 & 3 & 0 & 2 & 1 & 1 & 2 & 9 & $18.33 \%$ \\
\hline 40000 & 2 & 0 & 0 & 0 & 0 & 2 & 4 & $17.50 \%$ \\
\hline
\end{tabular}


Microfinance Recipients' Maximum Willingness to Pay for Microloans in Lahore

\begin{tabular}{|l|l|l|l|l|l|l|l|l|}
\hline $40000 @ 2$ & 0 & 1 & 8 & 0 & 0 & 1 & 10 & $19.00 \%$ \\
\hline Totals & 0 & 9 & 61 & 16 & 23 & 19 & 206 & \\
\hline
\end{tabular}

Table 12: WTP by customers earning PKR 10000 to PKR15000

\begin{tabular}{|l|l|l|l|l|l|l|l|l|}
\hline $\begin{array}{l}\text { Loan } \\
\text { Levels }\end{array}$ & $\mathbf{3 0 \%}$ & $\mathbf{2 5 \%}$ & $\mathbf{2 0 \%}$ & $\mathbf{1 5 \%}$ & $\mathbf{1 0 \%}$ & $\mathbf{5 \%}$ & Totals & AMWTP \\
\hline 5000 & 36 & 2 & 4 & 0 & 2 & 1 & 45 & $27.44 \%$ \\
\hline 10000 & 29 & 3 & 8 & 1 & 1 & 1 & 43 & $26.40 \%$ \\
\hline 15000 & 19 & 3 & 10 & 4 & 2 & 0 & 38 & $24.34 \%$ \\
\hline 20000 & 16 & 1 & 8 & 2 & 5 & 0 & 32 & $23.28 \%$ \\
\hline 25000 & 11 & 0 & 5 & 0 & 2 & 4 & 22 & $21.36 \%$ \\
\hline 30000 & 9 & 0 & 3 & 1 & 1 & 1 & 15 & $24.00 \%$ \\
\hline 40000 & 4 & 1 & 2 & 0 & 0 & 1 & 8 & $23.75 \%$ \\
\hline $40000 @ 2$ & 9 & 4 & 3 & 0 & 1 & 1 & 18 & $24.72 \%$ \\
\hline Totals & 159 & 17 & 56 & 8 & 17 & 14 & 271 & \\
\hline
\end{tabular}

Table 13: WTP by customers earning between PKR15000 to PKR20000

\begin{tabular}{|l|l|l|l|l|l|l|l|l|}
\hline Loan Levels & $\mathbf{3 0 \%}$ & $\mathbf{2 5 \%}$ & $\mathbf{2 0 \%}$ & $\mathbf{1 5 \%}$ & $\mathbf{1 0 \%}$ & $\mathbf{5 \%}$ & Totals & AMWTP \\
\hline 5000 & 12 & 1 & 1 & 1 & 0 & 0 & 15 & $28.00 \%$ \\
\hline 10000 & 10 & 1 & 2 & 1 & 0 & 0 & 14 & $27.14 \%$ \\
\hline 15000 & 10 & 1 & 0 & 2 & 1 & 0 & 14 & $26.07 \%$ \\
\hline 20000 & 6 & 1 & 2 & 1 & 0 & 0 & 10 & $26.00 \%$ \\
\hline 25000 & 5 & 0 & 1 & 0 & 2 & 0 & 8 & $23.75 \%$ \\
\hline 30000 & 3 & 0 & 1 & 1 & 1 & 0 & 6 & $22.50 \%$ \\
\hline 40000 & 2 & 0 & 0 & 0 & 0 & 0 & 2 & $30.00 \%$ \\
\hline 40000 @ 2 & 4 & 0 & 3 & 0 & 0 & 0 & 7 & $25.71 \%$ \\
\hline Totals & 66 & 5 & 15 & 6 & 4 & 0 & 96 & \\
\hline
\end{tabular}

Table 14: WTP by customers earning greater than PKR20000

\begin{tabular}{|l|l|l|l|l|l|l|l|l|}
\hline Loan Levels & $\mathbf{3 0 \%}$ & $\mathbf{2 5 \%}$ & $\mathbf{2 0 \%}$ & $\mathbf{1 5 \%}$ & $\mathbf{1 0 \%}$ & $\mathbf{5 \%}$ & Totals & AMWTP \\
\hline 5000 & 5 & 1 & 1 & 0 & 0 & 0 & 7 & $27.86 \%$ \\
\hline 10000 & 3 & 1 & 1 & 0 & 0 & 0 & 5 & $27.00 \%$ \\
\hline 15000 & 3 & 1 & 1 & 0 & 0 & 0 & 5 & $27.00 \%$ \\
\hline 20000 & 3 & 1 & 0 & 0 & 1 & 0 & 5 & $25.00 \%$ \\
\hline 25000 & 2 & 1 & 1 & 0 & 1 & 0 & 5 & $23.00 \%$ \\
\hline 30000 & 2 & 0 & 0 & 1 & 1 & 0 & 4 & $21.25 \%$ \\
\hline 40000 & 2 & 0 & 0 & 0 & 0 & 0 & 2 & $30.00 \%$ \\
\hline $40000 @ 2$ & 0 & 0 & 2 & 0 & 0 & 0 & 2 & $20.00 \%$ \\
\hline Totals & 29 & 5 & 10 & 1 & 3 & 1 & 49 & \\
\hline
\end{tabular}

Table 15: WTP by customers where Head of Household is "Father"

\begin{tabular}{|l|l|l|l|l|l|l|l|l|}
\hline Loan Levels & $\mathbf{3 0 \%}$ & $\mathbf{2 5 \%}$ & $\mathbf{2 0 \%}$ & $\mathbf{1 5 \%}$ & $\mathbf{1 0 \%}$ & $\mathbf{5 \%}$ & Totals & AMWTP \\
\hline 5000 & 21 & 5 & 6 & 1 & 3 & 2 & 38 & $24.47 \%$ \\
\hline 10000 & 11 & 5 & 8 & 2 & 3 & 2 & 31 & $22.10 \%$ \\
\hline 15000 & 7 & 3 & 10 & 4 & 2 & 0 & 26 & $21.73 \%$ \\
\hline 20000 & 2 & 2 & 10 & 2 & 5 & 0 & 21 & $18.57 \%$ \\
\hline 25000 & 2 & 1 & 3 & 0 & 2 & 5 & 13 & $14.62 \%$ \\
\hline 30000 & 2 & 0 & 3 & 0 & 1 & 1 & 7 & $19.29 \%$ \\
\hline 40000 & 0 & 1 & 1 & 0 & 0 & 0 & 2 & $22.50 \%$ \\
\hline $40000 @ 2$ & 2 & 1 & 8 & 0 & 1 & 0 & 12 & $21.25 \%$ \\
\hline Totals & 52 & 19 & 62 & 10 & 18 & 16 & 177 & \\
\hline
\end{tabular}


Microfinance Recipients' Maximum Willingness to Pay for Microloans in Lahore

Table 16: WTP by customers where Head of Household is "Female"

\begin{tabular}{|l|r|r|r|r|r|r|r|c|}
\hline Loan Levels & $\mathbf{3 0 \%}$ & $\mathbf{2 5 \%}$ & $\mathbf{2 0 \%}$ & $\mathbf{1 5 \%}$ & $\mathbf{1 0 \%}$ & $\mathbf{5 \%}$ & \multicolumn{1}{l}{ Total } & AMWTP \\
\hline 5000 & 8 & 0 & 2 & 0 & 0 & 0 & 10 & $28.00 \%$ \\
\hline 10000 & 5 & 0 & 4 & 0 & 0 & 1 & 10 & $23.50 \%$ \\
\hline 15000 & 3 & 0 & 3 & 0 & 0 & 2 & 8 & $20.00 \%$ \\
\hline 20000 & 2 & 0 & 2 & 0 & 1 & 0 & 5 & $22.00 \%$ \\
\hline 25000 & 1 & 0 & 2 & 0 & 1 & 0 & 4 & $20.00 \%$ \\
\hline 30000 & 1 & 0 & 1 & 0 & 1 & 0 & 3 & $20.00 \%$ \\
\hline 40000 & 0 & 0 & 0 & 0 & 0 & 1 & 1 & $5.00 \%$ \\
\hline $40000 @ 2$ & 2 & 1 & 1 & 0 & 0 & 0 & 4 & $26.25 \%$ \\
\hline Totals & 25 & 2 & 19 & 0 & 5 & 5 & 56 & \\
\hline
\end{tabular}

Table 17: WTP by customers where Head Of Household is "Husband"

\begin{tabular}{|l|l|l|l|l|l|l|l|l|}
\hline Loan Levels & $\mathbf{3 0 \%}$ & $\mathbf{2 5 \%}$ & $\mathbf{2 0 \%}$ & $\mathbf{1 5 \%}$ & $\mathbf{1 0 \%}$ & $\mathbf{5 \%}$ & Totals & AMWTP \\
\hline 5000 & 20 & 1 & 1 & 1 & 2 & 0 & 25 & $27.20 \%$ \\
\hline 10000 & 16 & 1 & 3 & 1 & 1 & 1 & 23 & $25.87 \%$ \\
\hline 15000 & 12 & 1 & 4 & 1 & 2 & 1 & 21 & $24.05 \%$ \\
\hline 20000 & 9 & 0 & 7 & 1 & 2 & 0 & 19 & $23.42 \%$ \\
\hline 25000 & 5 & 0 & 2 & 1 & 1 & 1 & 10 & $22.00 \%$ \\
\hline 30000 & 4 & 0 & 0 & 2 & 0 & 0 & 6 & $25.00 \%$ \\
\hline 40000 & 2 & 0 & 0 & 0 & 0 & 1 & 3 & $21.67 \%$ \\
\hline $40000 @ 2$ & 6 & 0 & 2 & 0 & 0 & 1 & 9 & $25.00 \%$ \\
\hline Totals & 89 & 3 & 24 & 7 & 10 & 8 & 141 & \\
\hline
\end{tabular}

Table18: WTP by customers where Head of Household is "Joint (Husband and Wife)"

\begin{tabular}{|l|l|l|l|l|l|l|l|l|}
\hline Loan Levels & $\mathbf{3 0 \%}$ & $\mathbf{2 5 \%}$ & $\mathbf{2 0 \%}$ & $\mathbf{1 5 \%}$ & $\mathbf{1 0 \%}$ & $\mathbf{5 \%}$ & Totals & AMWTP \\
\hline 5000 & 35 & 0 & 2 & 1 & 1 & 0 & 39 & $28.59 \%$ \\
\hline 10000 & 25 & 2 & 6 & 2 & 1 & 1 & 37 & $26.08 \%$ \\
\hline 15000 & 19 & 2 & 5 & 6 & 3 & 1 & 36 & $23.47 \%$ \\
\hline 20000 & 12 & 2 & 4 & 3 & 3 & 1 & 25 & $22.80 \%$ \\
\hline 25000 & 10 & 0 & 3 & 0 & 4 & 0 & 17 & $23.53 \%$ \\
\hline 30000 & 9 & 0 & 1 & 1 & 2 & 2 & 15 & $22.33 \%$ \\
\hline 40000 & 7 & 0 & 1 & 0 & 0 & 0 & 8 & $28.75 \%$ \\
\hline $40000 @ 2$ & 3 & 3 & 5 & 0 & 0 & 1 & 12 & $22.50 \%$ \\
\hline Totals & 145 & 12 & 32 & 13 & 14 & 7 & 223 & \\
\hline
\end{tabular}

Table 19: WTP by customers where Head of Household is "Other"

\begin{tabular}{|l|l|l|l|l|l|l|l|l|}
\hline Loan Levels & $\mathbf{3 0 \%}$ & $\mathbf{2 5 \%}$ & $\mathbf{2 0 \%}$ & $\mathbf{1 5 \%}$ & $\mathbf{1 0 \%}$ & $\mathbf{5 \%}$ & Totals & AMWTP \\
\hline 5000 & 8 & 0 & 0 & 0 & 0 & 0 & 8 & $30.00 \%$ \\
\hline 10000 & 6 & 0 & 2 & 0 & 0 & 0 & 8 & $27.50 \%$ \\
\hline 15000 & 4 & 0 & 0 & 0 & 0 & 0 & 4 & $30.00 \%$ \\
\hline 20000 & 3 & 0 & 0 & 0 & 0 & 0 & 3 & $30.00 \%$ \\
\hline 25000 & 3 & 0 & 0 & 0 & 0 & 0 & 3 & $30.00 \%$ \\
\hline 30000 & 1 & 0 & 1 & 1 & 0 & 0 & 3 & $21.67 \%$ \\
\hline 40000 & 1 & 0 & 0 & 0 & 0 & 1 & 2 & $17.50 \%$ \\
\hline $40000 @ 2$ & 1 & 0 & 1 & 0 & 0 & 0 & 2 & $25.00 \%$ \\
\hline Totals & 33 & 0 & 9 & 1 & 0 & 1 & 44 & \\
\hline
\end{tabular}


Microfinance Recipients' Maximum Willingness to Pay for Microloans in Lahore

Table 20: WTP in Households where Proportion Educated is "0"

\begin{tabular}{|l|r|r|r|r|r|r|r|r|}
\hline $\begin{array}{c}\text { Loan } \\
\text { Levels }\end{array}$ & $\mathbf{3 0 \%}$ & $\mathbf{2 5 \%}$ & $\mathbf{2 0 \%}$ & $\mathbf{1 5 \%}$ & $\mathbf{1 0 \%}$ & $\mathbf{5 \%}$ & Totals & AMWTP \\
\hline 5000 & 29 & 3 & 5 & 1 & 2 & 2 & 42 & $25.95 \%$ \\
\hline 10000 & 14 & 4 & 11 & 5 & 1 & 3 & 38 & $22.11 \%$ \\
\hline 15000 & 10 & 2 & 10 & 5 & 1 & 2 & 30 & $21.50 \%$ \\
\hline 20000 & 5 & 0 & 9 & 3 & 1 & 3 & 21 & $19.05 \%$ \\
\hline 25000 & 5 & 0 & 2 & 1 & 2 & 4 & 14 & $17.50 \%$ \\
\hline 30000 & 3 & 0 & 2 & 1 & 1 & 0 & 7 & $22.14 \%$ \\
\hline 40000 & 0 & 0 & 1 & 0 & 0 & 1 & 2 & $12.50 \%$ \\
\hline $40000 @ 2$ & 1 & 2 & 5 & 0 & 0 & 0 & 8 & $22.50 \%$ \\
\hline Totals & 77 & 12 & 52 & 17 & 9 & 20 & 187 & \multicolumn{1}{c}{} \\
\cline { 1 - 5 } & & & & & & & &
\end{tabular}

Table 21: WTP in households where Proportion Educated is between 0 and 1

\begin{tabular}{|l|r|r|r|r|r|r|r|c|}
\hline Loan Levels & \multicolumn{1}{|c|}{$\mathbf{3 0 \%}$} & \multicolumn{1}{|c|}{$\mathbf{2 5 \%}$} & \multicolumn{1}{|c|}{$\mathbf{2 0 \%}$} & \multicolumn{1}{|c|}{$\mathbf{1 5 \%}$} & \multicolumn{1}{|c|}{$\mathbf{1 0 \%}$} & $\mathbf{5 \%}$ & \multicolumn{1}{c|}{ Totals } & AMWTP \\
\hline 5000 & 41 & 4 & 3 & 2 & 3 & 1 & 54 & $26.94 \%$ \\
\hline 10000 & 33 & 3 & 7 & 1 & 4 & 2 & 50 & $25.40 \%$ \\
\hline 15000 & 21 & 3 & 9 & 5 & 3 & 1 & 42 & $23.69 \%$ \\
\hline 20000 & 15 & 1 & 11 & 2 & 6 & 1 & 36 & $21.94 \%$ \\
\hline 25000 & 11 & 0 & 6 & 0 & 2 & 1 & 20 & $23.75 \%$ \\
\hline 30000 & 8 & 0 & 3 & 2 & 1 & 2 & 16 & $21.88 \%$ \\
\hline 40000 & 5 & 0 & 1 & 0 & 0 & 1 & 7 & $25.00 \%$ \\
\hline $40000 @ 2$ & 9 & 1 & 6 & 0 & 1 & 2 & 19 & $22.89 \%$ \\
\hline Totals & 168 & 14 & 62 & 12 & 23 & 12 & 291 & \\
\hline
\end{tabular}

Table 22: WTP in households where Proportion Educated is "1"

\begin{tabular}{|l|r|r|r|r|r|r|r|r|}
\hline Loan Levels & \multicolumn{1}{|c|}{$\mathbf{3 0 \%}$} & \multicolumn{1}{|c|}{$\mathbf{2 5 \%}$} & \multicolumn{1}{|c|}{$\mathbf{1 0 \%}$} & \multicolumn{1}{|c|}{$\mathbf{1 5 \%}$} & \multicolumn{1}{|c|}{$\mathbf{5 \%}$} & Totals & AMWTP \\
\hline 5000 & 28 & 1 & 5 & 0 & 1 & 0 & 35 & $27.86 \%$ \\
\hline 10000 & 20 & 3 & 8 & 0 & 0 & 1 & 32 & $26.25 \%$ \\
\hline 15000 & 17 & 2 & 6 & 2 & 3 & 2 & 32 & $23.44 \%$ \\
\hline 20000 & 10 & 3 & 6 & 2 & 4 & 0 & 25 & $22.60 \%$ \\
\hline 25000 & 7 & 1 & 3 & 0 & 4 & 4 & 19 & $18.68 \%$ \\
\hline 30000 & 6 & 0 & 2 & 1 & 3 & 1 & 13 & $20.77 \%$ \\
\hline 40000 & 5 & 1 & 0 & 0 & 0 & 1 & 7 & $25.71 \%$ \\
\hline $40000 @ 2$ & 5 & 2 & 7 & 0 & 0 & 0 & 14 & $24.29 \%$ \\
\hline Totals & 118 & 15 & 47 & 5 & 16 & 15 & 216 & \\
\hline
\end{tabular}

Table 23: WTP by customers who intend to use the Loan for running a "Business"

\begin{tabular}{|l|l|l|l|l|l|l|l|l|}
\hline Loan Levels & $\mathbf{3 0 \%}$ & $\mathbf{2 5 \%}$ & $\mathbf{2 0 \%}$ & $\mathbf{1 5 \%}$ & $\mathbf{1 0 \%}$ & $\mathbf{5 \%}$ & Total & AMWTP \\
\hline 5000 & 41 & 4 & 6 & 2 & 4 & 2 & 59 & $25.93 \%$ \\
\hline 10000 & 26 & 7 & 10 & 3 & 3 & 4 & 53 & $23.58 \%$ \\
\hline 15000 & 18 & 4 & 14 & 6 & 2 & 3 & 47 & $22.23 \%$ \\
\hline 20000 & 11 & 2 & 15 & 3 & 2 & 0 & 33 & $22.58 \%$ \\
\hline 25000 & 8 & 1 & 7 & 1 & 3 & 3 & 23 & $20.22 \%$ \\
\hline 30000 & 7 & 0 & 5 & 3 & 0 & 2 & 17 & $21.47 \%$ \\
\hline 40000 & 4 & 0 & 2 & 0 & 0 & 3 & 9 & $19.44 \%$ \\
\hline $40000 @ 2$ & 5 & 2 & 9 & 0 & 1 & 0 & 17 & $22.94 \%$ \\
\hline Total & 142 & 23 & 94 & 19 & 16 & 24 & 318 & \\
\hline
\end{tabular}


Table 24: WTP by customers who intend to "Buy Equipment"

\begin{tabular}{|l|l|l|l|l|l|l|l|l|}
\hline Loan Levels & $\mathbf{3 0 \%}$ & $\mathbf{2 5 \%}$ & $\mathbf{2 0 \%}$ & $\mathbf{1 5 \%}$ & $\mathbf{1 0 \%}$ & $\mathbf{5 \%}$ & Totals & AMWTP \\
\hline 5000 & 16 & 0 & 3 & 0 & 1 & 0 & 20 & $27.50 \%$ \\
\hline 10000 & 11 & 1 & 6 & 1 & 0 & 0 & 19 & $25.79 \%$ \\
\hline 15000 & 7 & 2 & 4 & 3 & 1 & 0 & 17 & $23.24 \%$ \\
\hline 20000 & 3 & 0 & 6 & 1 & 5 & 0 & 15 & $18.33 \%$ \\
\hline 25000 & 3 & 0 & 1 & 0 & 1 & 1 & 6 & $20.83 \%$ \\
\hline 30000 & 2 & 0 & 1 & 0 & 1 & 1 & 5 & $19.00 \%$ \\
\hline 40000 & 1 & 0 & 0 & 0 & 0 & 0 & 1 & $30.00 \%$ \\
\hline 40000 @ 2 & 5 & 1 & 2 & 0 & 0 & 1 & 9 & $24.44 \%$ \\
\hline Totals & 55 & 5 & 25 & 5 & 12 & 4 & 106 & \\
\hline
\end{tabular}

Table 25: WTP by customers who intend to "Buy Property" with the loan

\begin{tabular}{|l|l|l|l|l|l|l|l|l|}
\hline Loan Levels & $\mathbf{3 0 \%}$ & $\mathbf{2 5 \%}$ & $\mathbf{2 0 \%}$ & $\mathbf{1 5 \%}$ & $\mathbf{1 0 \%}$ & $\mathbf{5 \%}$ & Totals & AMWTP \\
\hline 5000 & 16 & 1 & 1 & 1 & 0 & 0 & 19 & $28.42 \%$ \\
\hline 10000 & 10 & 0 & 4 & 1 & 1 & 1 & 17 & $24.12 \%$ \\
\hline 15000 & 6 & 0 & 2 & 1 & 3 & 0 & 12 & $22.08 \%$ \\
\hline 20000 & 4 & 1 & 1 & 0 & 1 & 1 & 8 & $22.50 \%$ \\
\hline 25000 & 3 & 0 & 0 & 0 & 0 & 2 & 5 & $20.00 \%$ \\
\hline 30000 & 3 & 0 & 0 & 0 & 0 & 0 & 3 & $30.00 \%$ \\
\hline 40000 & 2 & 1 & 0 & 0 & 0 & 0 & 3 & $28.33 \%$ \\
\hline $40000 @ 2$ & 1 & 0 & 3 & 0 & 0 & 1 & 5 & $19.00 \%$ \\
\hline Totals & 55 & 3 & 12 & 3 & 6 & 7 & 86 & \\
\hline
\end{tabular}

Table 26: WTP by customers who intend to "Purchase Raw Materials" with the loan

\begin{tabular}{|l|l|l|l|l|l|l|l|l|}
\hline Loan Levels & $\mathbf{3 0 \%}$ & $\mathbf{2 5 \%}$ & $\mathbf{2 0 \%}$ & $\mathbf{1 5 \%}$ & $\mathbf{1 0 \%}$ & $\mathbf{5 \%}$ & Totals & AMWTP \\
\hline 5000 & 8 & 1 & 0 & 0 & 0 & 0 & 9 & $29.44 \%$ \\
\hline 10000 & 7 & 0 & 1 & 0 & 0 & 0 & 8 & $28.75 \%$ \\
\hline 15000 & 5 & 0 & 1 & 0 & 0 & 1 & 7 & $25.00 \%$ \\
\hline 20000 & 2 & 0 & 1 & 1 & 1 & 0 & 5 & $21.00 \%$ \\
\hline 25000 & 1 & 0 & 1 & 0 & 0 & 0 & 2 & $25.00 \%$ \\
\hline 30000 & 0 & 0 & 0 & 0 & 0 & 0 & 0 & NA \\
\hline 40000 & 0 & 0 & 0 & 0 & 0 & 0 & 0 & NA \\
\hline 40000 @ 2 & 3 & 0 & 1 & 0 & 0 & 0 & 4 & $27.50 \%$ \\
\hline Totals & 30 & 1 & 7 & 1 & 1 & 2 & 42 & \\
\hline
\end{tabular}

Table 27: WTP by customers who intend to "Expand the established Business"

\begin{tabular}{|l|l|l|l|l|l|l|l|l|}
\hline Loan Levels & $\mathbf{3 0 \%}$ & $\mathbf{2 5 \%}$ & $\mathbf{2 0 \%}$ & $\mathbf{1 5 \%}$ & $\mathbf{1 0 \%}$ & $\mathbf{5 \%}$ & Totals & AMWTP \\
\hline 5000 & 11 & 0 & 1 & 0 & 1 & 0 & 13 & $27.69 \%$ \\
\hline 10000 & 9 & 0 & 2 & 0 & 1 & 0 & 12 & $26.67 \%$ \\
\hline 15000 & 9 & 0 & 1 & 1 & 1 & 0 & 12 & $26.25 \%$ \\
\hline 20000 & 8 & 1 & 0 & 1 & 2 & 0 & 12 & $25.00 \%$ \\
\hline 25000 & 6 & 0 & 1 & 0 & 4 & 0 & 11 & $21.82 \%$ \\
\hline 30000 & 5 & 0 & 0 & 1 & 3 & 0 & 9 & $21.67 \%$ \\
\hline 40000 & 3 & 0 & 0 & 0 & 0 & 0 & 3 & $30.00 \%$ \\
\hline $40000 @ 2$ & 0 & 2 & 2 & 0 & 0 & 0 & 4 & $22.50 \%$ \\
\hline Totals & 62 & 4 & 8 & 3 & 12 & 0 & 89 & \\
\hline
\end{tabular}


Table 28: WTP by customers who intend to use loan for "Other" purposes such as Education and

\begin{tabular}{|l|l|l|l|l|l|l|l|l|}
\hline Loan Levels & $\mathbf{3 0 \%}$ & $\mathbf{2 5 \%}$ & $\mathbf{2 0 \%}$ & $\mathbf{1 5 \%}$ & $\mathbf{1 0 \%}$ & $\mathbf{5 \%}$ & Totals & AMWTP \\
\hline 5000 & 20 & 1 & 3 & 1 & 3 & 0 & 28 & $26.07 \%$ \\
\hline 10000 & 10 & 2 & 5 & 3 & 3 & 3 & 26 & $20.77 \%$ \\
\hline 15000 & 3 & 1 & 6 & 3 & 5 & 3 & 21 & $16.43 \%$ \\
\hline 20000 & 2 & 1 & 3 & 2 & 2 & 4 & 14 & $15.36 \%$ \\
\hline 25000 & 2 & 0 & 1 & 1 & 2 & 1 & 7 & $17.14 \%$ \\
\hline 30000 & 0 & 0 & 2 & 2 & 0 & 1 & 5 & $15.00 \%$ \\
\hline 40000 & 0 & 0 & 0 & 0 & 1 & 0 & 1 & $10.00 \%$ \\
\hline $40000 @ 2$ & 3 & 0 & 3 & 1 & 1 & 3 & 11 & $17.27 \%$ \\
\hline Totals & 44 & 5 & 26 & 13 & 21 & 20 & 129 & \\
\hline
\end{tabular}

